\title{
PENGARUH KOMPENSASI, KEDISIPLINAN DAN PENGALAMAN KERJA TERHADAP KINERJA KARYAWAN PADA PT. ANDRE TEKNIK MANDIRI SURABAYA
}

\author{
Asep Saefulloh, Roziana Ainul Hidayati, Etika Asia Fahmi \\ Program Studi Manajemen Fakultas Ekonomi dan Bisnis \\ Universitas Muhammadiyah Gresik
}

\begin{abstract}
This study aims to examine the effects of compensation, discipline and work experience on employee performance. The number of samples in this study 44 employees at PT. Andre Teknik Mandiri Surabaya. Data analysis used is multiple linear regression analysis. The results of this study conclude that the results of partial compensation test have an effect on and significant to performance, discipline also have an effect and significant to performance and work experience have an effect on and signifikan to performance.
\end{abstract}

Keywords : Compensation, Discipline, Work Experience and Performance

\section{PENDAHULUAN}

Persaingan usaha semakin kompetitif sehingga menuntut perusahaan untuk mampu beradaptasi agar terhindar dari kebangkrutan dan unggul dalam persaingan, untuk megantisipasi persaingan perusahaan harus mampu berkompetisi, yang dapat dilakukan antara lain dengan cara memperkuat kapasitas organisasi dan sumber daya manusia yang dimiliki. Manajemen sumber daya manusia adalah suatu proses menangani berbagai masalah pada ruang lingkup pegawai, pegawai buruh, manajer dan tenaga kerja lainnya untuk mencapai tujuan yang telah ditetapkan perusahaan (Sinambela, 2016;8).

Karyawan PT. Andre Teknik Mandiri di tuntut untuk mampu menyelesaikan tugas dan tanggung jawabnya secara efektif dan efesien untuk memenuhi, mempermudah memecahkan masalah dan sikap pelayanan, perawatan tower telekomunikasi di bidang kontraktor listrik, sehingga perusahaan akan dapat bertahan dalam persaingan global.

Kinerja menurut Prawirosentono (dalam Sinambela, 2016;481) adalah hasil kerja yang dapat dicapai oleh seseorang atau sekelompok orang dalam organisasi, sesuai dengan wewenang dan tanggung jawab masing-masing dalam rangka upaya mencapai tujuan organisasi bersangkutan secara legal, tidak melanggar hukum dan sesuai dengan moral maupun etika.

Menurut Prawirosentono (dalam Sinambela, 2016;481) oleh karena itu dalam sebuah organisasi untuk mencapai kinerja yang maksimal diperlukan perlakuan yang adil dan memuaskan pada sumber daya manusia yang bekerja pada organisasi tersebut, dengan adanya kinerja yang tinggi yang dimiliki karyawan, maka diharapkan tujuan organisasi dapat tercapai. Berikut ini Penilaian Kinerja Karyawan di PT. Andre Teknik Mandiri Surabaya yang dapat dilihat pada tabel 1.1. 
Tabel 1.1 Penilaian Kinerja

PT. Andre Teknik Mandiri Surabaya Periode 2017

\begin{tabular}{|c|c|c|c|c|c|c|c|}
\hline No & Bulan & $\begin{array}{c}\text { Target Perbulan } \\
\text { Karyawan Dalam } \\
\text { Menangani Masalah }\end{array}$ & $\begin{array}{c}\text { Pencapaian Perbulan } \\
\text { Karyawan Dalam } \\
\text { Menangani Masalah }\end{array}$ & $\begin{array}{c}\text { Hasil } \\
\text { Keterangan }\end{array}$ & $\begin{array}{c}\text { Target Perbulan Ketepatan } \\
\text { Waktu Karyawan } \\
\text { Terhadap Sikap Pelayanan }\end{array}$ & $\begin{array}{c}\text { Pencapaian Perbulan } \\
\text { Ketepatan Waktu Karyawan } \\
\text { Terhadap Sikap Pelayanan }\end{array}$ & $\begin{array}{c}\text { Hasil } \\
\text { Keterangan }\end{array}$ \\
\hline 1 & Januari & 100 & 78 & Baik & 100 & 75 & Baik \\
\hline 2 & Febuari & 100 & 75 & Baik & 100 & 79 & Baik \\
\hline 3 & Maret & 100 & 70 & Cukup & 100 & 75 & Baik \\
\hline 4 & April & 100 & 70 & Cukup & 100 & 76 & Baik \\
\hline 5 & Mei & 100 & 65 & Cukup & 100 & 76 & Baik \\
\hline 6 & Juni & 100 & 68 & Cukup & 100 & 70 & Cukup \\
\hline 7 & Juli & 100 & 70 & Cukup & 100 & 70 & Cukup \\
\hline 8 & $\begin{array}{c}\text { Agustu } \\
\text { S }\end{array}$ & 100 & 78 & Baik & 100 & 79 & Baik \\
\hline 9 & $\begin{array}{c}\text { Septemb } \\
\text { er }\end{array}$ & 100 & 75 & Baik & 100 & 75 & Baik \\
\hline $\begin{array}{c}10 \\
\text { Oktobe } \\
\text { r }\end{array}$ & 100 & 72 & Baik & 100 & 74 & Baik \\
\hline $\begin{array}{c}11 \\
\text { Novemb } \\
\text { er }\end{array}$ & 100 & 70 & Cukup & 100 & 72 & Baik \\
\hline
\end{tabular}

Sumber : Bagian Sumber Daya Manusia (data diolah)

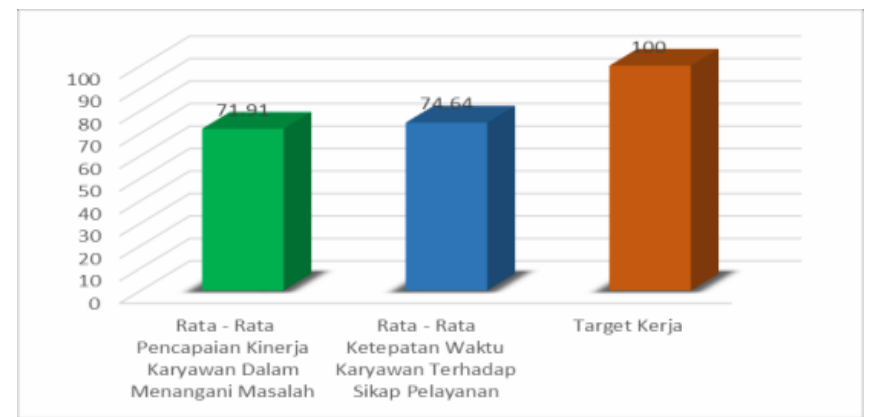

Gambar 1.1

Rata - Rata Penilaian Kinerja Karyawan Terhadap Penanganan Masalah Dan Ketepatan Waktu Karyawan Terhadap Sikap Pelayanan PT.

Andre Teknik Mandiri Surabaya Bulan Januari - November 2017

Berdasarkan data pada Tabel 1.1 di atas menunjukkan bahwa, adanya perbandingan antara target penilaian kerja dengan pencapaian perbulan penilaian di kinerja karyawan. Indikator dari penilaian kinerja karyawan di PT. Andre Teknik Mandiri Surabaya tersebut adalah dapat dinilai dari kualitas kerja, ketepatan waktu dalam menyelesaikan pekerjaan, efektifitas, kemandirian, orientasi pelayanan, integrasi, dan kerja samanya.
Target penilaian kinerja karyawan dalam menangani masalah dan target ketepatan waktu karyawan terhadap sikap pelayanan di PT. Andre Teknik Mandiri Surabaya dengan capaian nilai 100. Sedangkan kriteria karyawan dalam menangani masalah pencapaian nilai perbulan mulai dari bulan Januari sampai Bulan November 2017 mencapai kurang dari 100, alasannya karena karyawan kurang memahami menangani masalah tentang kerusakan 
tower, dan faktor cuaca yang kurang mendukung. Begitu juga dengan kriteria pencapaian perbulan ketepatan waktu karyawan terhadap sikap pelayanan mulai dari Bulan Januari sampai Bulan November 2017, pencapaian nilainya kurang dari 100, alasannya karena karyawan kurangnya responsiveness karyawan terhadap kejadian, memiliki waktu yang lama, dan faktor cuaca yang kurang mendukung. Pada Gambar 1.1 menunjukkan hasil penilaian kinerja karyawan dari Bulan Januari sampai Bulan November 2017, rata-rata penilaian kriteria karyawan dalam menangani masalah mencapai nilai ratarata 71,91 maksud dari nilai rata-rata tersebut menunjukkan keterangan kategori baik, sedangkan untuk ketepatan waktu karyawan terhadap sikap pelayanan dari Bulan Januari sampai Bulan November 2017, rataratanya 76,64 maksud nilai rata-rata tersebut menunjukkan keterangan kategori baik. Sinambela $(2016 ; 217)$ kompensasi menjadi suatu alasan atau tujuan seseorang untuk bekerja, disisi lain kompensasi akan mempengaruhi perilaku serta sikap kerja karyawan sesuai dengan organisasi agar karyawan dapat meningkatkan kinerjanya, Sutrisno (2009;199). Berikut ini adalah data rekapitulasi daftar kompensasi pegawai di PT. Andre Teknik Mandiri Surabaya.

\section{Tabel 1.3}

Rekap Daftar Kompensasi Pegawai PT. Andre Teknik Mandiri Surabaya

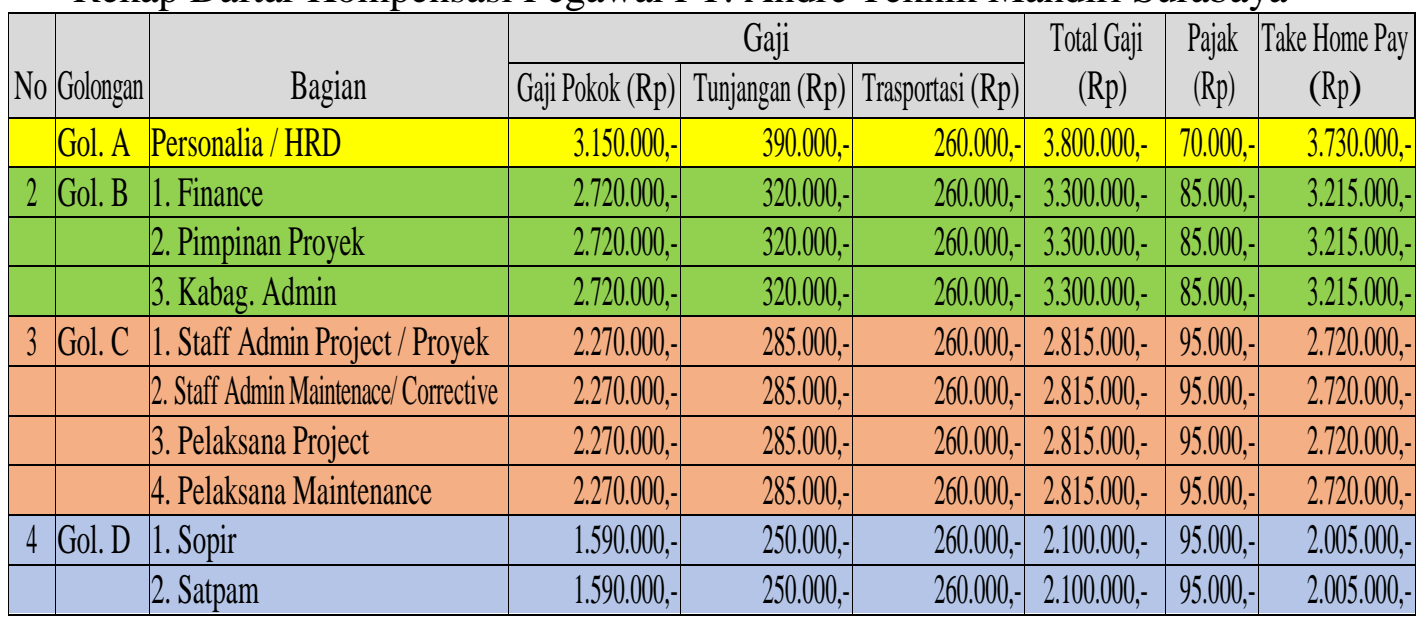

Sumber : PT. Andre Teknik Mandiri Surabaya; 2017

Berdasarkan Tabel 1.3 di atas Take Home Pay yang diterima di PT. Andre Teknik Mandiri Surabaya sebesar Rp.2.720.000 perBulan. Dibagian sopir dan satpam Take Home Pay yang diterima karyawan adalah Rp. 2.005.000 perBulan. Sedangkan UMR Surabaya tahun 2017 Rp. 3.583.312,61 perBulan untuk gaji yang di terima oleh setiap karyawan.

PT. Andre Teknik Mandiri Surabaya didapati masalah di bidang sumber daya manusia yaitu kedisiplinan, diukur dari indikator ketepatan waktu jam pulang, jam masuk, kepatuhan pada jam kerja, kesetiaan atau patuh pada peraturan dan tata tertib, menggunakan dan memelihara peralatan kerja, bahwasan tidak adanya sanksi yang tegas dari pemimpin terhadap karyawan yang bermasalah (tidak masuk tanpa keterangan) sehingga karyawan merasa hal yang wajar apabila tidak masuk tanpa disertai keterangan. Didukung dengan data rekapitulasi absensi karyawan yang tidak masuk tanpa disertai keterangan periode JanuariNovember 2017 PT. Andre Teknik Mandiri Surabaya. 
Tabel 1.3

Data Rekapitulasi Absensi karyawan Bulan Januari-November 2017

\begin{tabular}{|c|c|c|c|}
\hline No & Bulan & Tanpa Keterangan & Dengan Keterangan \\
\hline 1 & Januari & 7 & 3 \\
\hline 2 & Febuari & 4 & 1 \\
\hline 3 & Maret & 5 & 1 \\
\hline 4 & April & 3 & 2 \\
\hline 5 & Mei & 5 & 0 \\
\hline 6 & Juni & 0 & 0 \\
\hline 7 & Juli & 0 & 2 \\
\hline 8 & Agustus & 2 & 4 \\
\hline 9 & September & 3 & 1 \\
\hline 10 & Oktober & 4 & 2 \\
\hline 11 & November & 2 & 17 \\
\hline \multicolumn{2}{|l}{ Jumlah karyawan } & 35 & 17 \\
\hline
\end{tabular}

Sumber: PT. Andre Teknik Mandiri Surabaya; 2017

Berdasarkan Tabel 1.3, bahwa dari 47 karyawan yang ada di PT. Andre Teknik Mandiri Surabaya tentunya dalam setiap Bulan didapati adanya karyawan yang tidak masuk kerja tanpa disertai keterangan, berdasarkan data tabel diatas pada Bulan Januari sampai Bulan November 2017 karyawan yang tidak masuk kerja tanpa disertai keterangan berjumlah 35 karyawan. Dibandingkan dengan karyawan yang tidak masuk dengan keterangan dari Bulan Januari sampai Bulan November 2017 berjumlah 17 karyawan. Selisih dari perbandingan antara karyawan yang tidak masuk tanpa keterangan dan dengan keterangan berjumlah 18 karyawan yang tidak masuk kerja, menunjukkan adanya permasalahan tentang kedisiplinan kerja karyawan di PT. Andre Teknik Mandiri Surabaya. Selain itu didapati kondisi sebagian karyawan yang tidak mentaati peraturan perusahaan, hal itu terlihat dengan masih adanya karyawan yang masuk terlambat kerja pada setiap bulannya, hal itu didukung dengan data rekapitulasi karyawan yang terlambat.

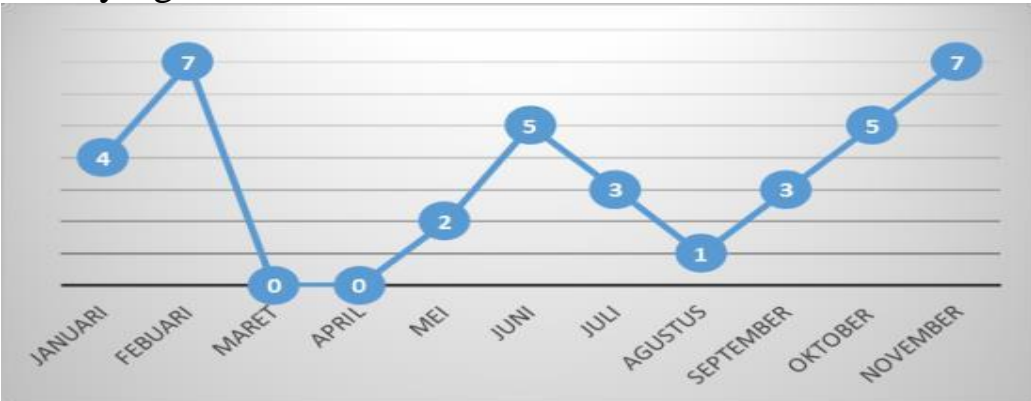

Sumber ; PT. Andre Teknik Mandiri Surabaya

Gambar 1.2 Rekapitulasi Karyawan Terlambat Berdasarkan Absensi Bulan Januari - November 2017 
Berdasarkan Gambar 1.2 di atas didapati karyawan yang terlambat pada Bulan Januari sampai Bulan November 2017 berjumlah 37 karyawan. Bulan Maret dan April 2017 tidak ada karyawan yang terlambat, tetapi di Bulan Febuari dan Bulan November jumlah terbanyak yang terlambat berdasarkan absensi berjumlah 7 karyawan. Adanya peningkatan pada Bulan Agustus sampai Bulan November dari data grafik diatas menunjukkan adanya permasalahan tentang kedisiplinan karyawan yang terlambat pada PT. Andre Teknik Mandiri Surabaya.

Pengalaman kerja didapatkkan pada karyawan yang telah memiliki jam kerja lebih banyak, pengalaman kerja banyak memberikan keahlian dan keterampilan dalam bekerja, dengan memperoleh pengalaman kerja karyawan mampu menyelesaikan tugas yang dibebankan dapat dikerjakan dengan baik, Rofi (2013;6), sedangkan pengalaman yang minim akan berimbas pada kinerja dan prestasi kerja rendah, dengan pengalaman kerja yang ada maka karyawan akan dapat mempermudah memecahkan masalah yang timbul. Hal ini didukung dengan tabel 1.4 berikut yang menunjukkan bahwa jumlah karyawan yang memiliki pengalaman kerja dan yang tidak memiliki pengalaman kerja pada PT. Andre Teknik Mandiri Surabaya.

Tabel 1.4

Jumlah karyawan yang memiliki pengalaman kerja dan yang tidak memiliki pengalaman kerja pada PT. Andre Teknik Mandiri Surabaya.

\begin{tabular}{|c|c|c|}
\hline Karyawan & Tidak Memiliki Pengalaman & Memiliki Pengalaman \\
\hline Kantor & 17 & 9 \\
\hline Lapangan & 14 & 7 \\
\hline Jumlah & 31 & 15 \\
\hline
\end{tabular}

Sumber: PT. Andre Teknik Mandiri Surabaya 2017

Berdasarkan data Tabel 1.4 didapati jumlah karyawan yang tidak memiliki pengalaman berjumlah 31 karyawan, indikatornya adalah karena masih pegawai baru, barusan lulus dari pendidikan terakhir, kurangnya tingkat pengetahuan, keterampilan yang dimiliki dan kurangnya penguasaan terhadap pekerjaan. Sedangkan jumlah karyawan yang memiliki pengalaman berjumlah 15 orang, indicator karyawan yang memiliki pengalaman kerja adalah karyawan masa kerjanya lama, tingkat pengetahuan, keterampilan yang dimiliki dan penguasaan pekerjaannya. Disimpulkan bahwa karyawan yang tidak memiliki pengalaman kerja lebih banyak dari pada jumlah karyawan yang memiliki pengalaman kerja. Berdasarkan uraian diatas peneliti mengambil tema mengenai "Pengaruh Kompensasi, Kedisiplinan Dan Pengalaman Kerja Terhadap Kinerja Karyawan Pada PT. Andre Teknik Mandiri Surabaya”.

\section{KAJIAN PUSTAKA}

Kompensasi

Menurut William dan Keith Davis (dalam Hasibuan, 2016;119) mendefinisikan kompensasi adalah sesuatu yang diterima karyawan sebagai pengganti kontribusi jasa mereka pada perusahaan, baik berupah upah per jam ataupun gaji periodik didesain dan dikelola bagian personalia. Menurut Singodimedjo (dalam Sutrisno 2013;183) kompensasi dapat diberikan dalam 
berbagai macam bentuk, seperti: dalam pemberian bentuk uang, pemberian materiil dan fasilitas, dan dalam bentuk pemberian kesempatan berkarir.

\section{Kedisiplinan}

Menurut Rivai dan Jauvani $(2013 ; 825)$ disiplin kerja adalah suatu alat yang digunakan para manajer untuk berkomunikasi dengan karyawan agar mereka bersedia untuk mengubah suatu perilaku serta sebagai suatu upaya untuk meningkatkan kesadaran dan kesediaan menaati semua peraturan perusahaan dan normanorma sosial yang berlaku. Terdapat tiga konsep pelaksanaan tindakan indisipliner dalam konsep Rivai dan Jauvani, yaitu: aturan tungku panas (hot stove rule), tindakan disiplin progresif (progressive discipline), dan tindakan disiplin positif (positive discipline).

Hasibuan

menjelaskan disiplin fungsi operatif dari manajemen sumber daya manusia yang terpenting karena semakin baik disiplin karyawan, semakin tinggi prestasi kerja yang dapat dicapainya, karena tanpa adanya disiplin karyawan yang baik, maka akan sulit bagi perusahaan untuk mencapai hasil yang optimal. Disiplin merupakan arahan untuk melatih dan membentuk seseorang melakukan sesuatu menjadi lebih baik. "Disiplin adalah suatu proses yang dapat menumbuhkan perasaan seseorang untuk mempertahankan dan meningkatkan tujuan organisasi secara objektif, melalui kepatuhannya menjalankan peraturan organisasi.

\section{Pengalaman Kerja}

Menurut Sastrohadiwiryo (2010;2) mendefinisikan Pengalaman kerja adalah sangat penting dalam menjalankan usaha suatu perusahaan, dengan memperoleh pengalaman kerja maka, tugas yang dibebankan dapat dikerjakan dengan baik, sedangkan pengalaman kerja sangat mempengaruhi kinerja karyawan karena dengan memiliki pengalaman kerja, maka prestasi kerja dan kinerja pun meningkat. Pengalaman diperoleh melalui suatu masa kerja, melalui pengalaman kerja seseorang secara sadar atau tidak sadar belajar, sehingga akhirnya dia akan memiliki kecakapan teknis, serta keterampilan dalam mengahadapi pekerjaan. Selain itu, dengan pengalaman kerja maka karyawan akan lebih mudah dalam menyelesaikan setiap pekerjaan yang dibebankan.Pengalaman kerja pada pekerjaan sejenis, perlu mendapatkan pertimbangan dalam penempatan tenaga kerja. kenyataannya menunjukkan makin lama tenaga kerja bekerja, makin banyak pengalaman yang dimiliki tenaga kerja yang bersangkutan. Sebaliknya, makin singkat masa kerja, makin sedikit pengalaman yang diperoleh.

\section{Kinerja}

Menurut Sinambela (2016;481), hasil kerja yang dapat dicapai oleh seseorang atau sekelompok orang dalam suatu organisasi sesuai dengan wewenang dan tanggung jawab masing-masing dalam rangka mencapai tujuan organisasi secara legal, tidak melanggar hukum dan sesuai dengan moral dan etika. Menurut Sinambela (2016;482) mengatakan bahwa kinerja merupakan hasil pekerjaan seorang karyawan selama periode tertentu dibandingkan dengan berbagai kemungkinan, misalnya standart, target atau sasaran atau kriteria yang telah ditentukan terlebih dahulu dan telah disepakati bersama. 


\section{Hipotesis}

1. Diduga kompensasi berpengaruh parsial terhadap kinerja karyawan pada PT. Andre Teknik Mandiri Surabaya.

2. Diduga kedisiplinan berpengaruh parsial terhadap kinerja karyawan pada PT. Andre Teknik Mandiri Surabaya.

3. Diduga pengalaman kerja berpengaruh parsial terhadap kinerja karyawan pada PT. Andre Teknik Mandiri Surabaya.

\section{METODE PENELITIAN \\ Populasi}

Menurut Sugiyono (2013;80), Populasi adalah wilayah generalisasi yang terdiri atas obyek yang mempunyai kualitas dan karakteristik tertentu yang ditetapkan oleh peneliti untuk dipelajari dan kemudian ditarik kesimpulannya. Adapun jumlah populasi penelitian ini sebanyak 46 karyawan tetap.

\section{Sampel}

Menurut Sugiyono (2013;81) menyatakan bahwa sampel adalah bagian dari jumlah dan karakteristik yang dimiliki oleh populasitersebut, jadi jumlah sampel dari populasi tertentu yang dikembangkan dari Isaac dan Michael (Sugiyono,2013;86), jika populasi 46 karyawan tetap tetap dan tingkat kesalahan 5\% maka sampel yang digunakan adalah 44 responden sebagaimana pada Pengambilan sampel menggunakan teknik propotionate stratified random sampling yang merupakan tekhnik pengambilan sampel bila suatu organisasi yang mempunyai karyawan tetap dari latar belakang jabatan atau staf yang berstrata.

\section{Definisi Variabel}

1. Variabel $(\mathrm{X})$

a. Kompensasi (X1)

Kompensasi adalah Pernyataan responden, kompensasi antara gaji, tunjangan kesehatan, bonus dan THR yang telah diberikan sebagai pengganti kontribusi jasa mereka pada perusahaan sebagai indikator:

1) Gaji

2) Tunjangan Kesehatan

3) THR

b. Kedisiplinan (X2)

Variabel Kedisiplinan adalah pernyataan responden terhadap ketaatan PT. Andre Teknik Mandiri Surabaya dengan indikator :

1) Ketepatan waktu meliputi ketepatan jam pulang, ketepatan jam masuk, kepatuhan pada jam kerja.

2) Kesetiaaan atau patuh pada peraturan dan tata tertib yang ada, meliputi kepatuhan untuk memakai seragam dan kepatuhan terhadap peraturan tata tertib dan komitmen yang telah disepakati.

3) Mempergunakan dan memelihara peralatan kerja.

c. Pengalaman Kerja (X3) Pengalaman kerja adalah pernyataan responden terhadap kesesuaian antara pemahaman tentang tugas yang diberikan dengan lama waktu atau masa kerjanya, tingkat pengetahuan dan keterampilan yang dimiliki, penguasaan terhadap pekerjaan dan peralatan dalam menjalankan tugastugas yang dibebankan kepadanya yang selalu berpengaruh besar terhadap tingkah laku manusia. Variabel pengalaman kerja sebagai variable independen (X3) pada pegawai PT. Andre Teknik Mandiri Surabaya, sebagai indikator:

1) Lama waktu / masa kerja.

2) Tingkat pengetahuan dan keterampilan yang dimiliki.

3) Penguasaan terhadap pekerjaan dan peralatan. 
2. Variabel (Y)

Kinerja Karyawan (Y)

Kinerja dapat diartikan sebagai penilaian atasan langsung terhadap hasil kerja yang dicapai oleh bawahan sesuai dengan standar dan kriteria yang ditetapkan, mengenai hasil kerja secara kualitas yang dicapai oleh seorang pegawai dalam melaksanakan tugas sesuai dengan tanggungjawab yang diberikan kepadanya. Kinerja karyawan sebagai variabel dependen $(\mathrm{Y})$ pada pegawai PT. Andre Teknik Mandiri Surabaya yang akan dinilai oleh atasan responden sebagai indikator :

1. Kualitas kerja, meliputi ketepatan, dan keberhasilan.

2. Ketepatan waktu dalam menyelesaikan pekerjaan.

3. Efektivitas, merupakan tingkat penggunaan sumber daya organisasi (tenaga, teknologi, uang, bahan baku) dimaksimalkan dengan maksud menaikkan hasil dari setiap unit dalam penggunaan sumber daya.

4. Kemandirian, tingkat karyawan yang nantinya akan dapat menjalankan fungsi kerjanya.

5. Orientasi pelayanan, merupakan sikap dan perilaku kerja dalam memberikan pelayanan terbaik kepada yang dilayani.

6. Integrasi, merupakan suatu konsep yang menunjuk konsistensi antara tindakan dengan nilai dan prinsip, diartikan sebagai kejujuran dan kebenaran dari tindakan seseorang.

7. Kerja sama, merupakan sebuah usaha yang dilakukan oleh beberapa orang atau kelompok untuk mencapai tujuan bersama.

\section{HASIL PENELITIAN}

\section{Uji Validitas \& Reliabilitas}

\section{Validitas}

Hasil dari uji validitas instrumen semua variabel didapatkan $r$ hitung $>r$ tabel 0,2973. Jadi sepuluh pernyataan dari variable independen maupuun dependen terbukti valid

\section{Reliabilitas}

Hasil masing-masing variable nilai Cronbach Alpha lebih besar dari 0,60. Dengan demikian dapat disimpulkan bahwa alat ukur yang digunakan dalam penelitian ini adalah reliable.

\section{Analisis Uji Asumsi Klasik}

1. Uji Autokorelasi

Tabel 4.1

Nilai Durbin Watson

\begin{tabular}{|l|c|c|}
\hline & Nilai & Keterangan \\
\hline Durbin Watson & 2.182 & Tidak ada autokorelasi \\
\hline
\end{tabular}

Sumber: Lampiran 5

Berdasarkan tabel 4.1 diatas menunjukkan bahwa nilai Durbin Watson 2.182 terletak antara batas atas du (1.6647) dan 4-du (2.336), maka dapat disimpulkan tidak terdapat autokorelasi pada model regresi ini.

\section{Uji Multikolinearitas}


Tabel 4.2

Koefisien tolerance dan VIF value Masing-masing variabel

\begin{tabular}{|l|l|l|l|}
\hline Variabel Bebas & Tolerance Value & VIF & Keterangan \\
\hline Kompensasi $\left(\mathrm{X}_{1}\right)$ & 0,862 & 1.160 & Nonmultikolinieritas \\
\hline Kedisiplinan $\left(\mathrm{X}_{2}\right)$ & 0,862 & 1.234 & Nonmultikolinieritas \\
\hline Pengalaman kerja $\left(\mathrm{X}_{3}\right)$ & 0,862 & 1.112 & Nonmultikolinieritas \\
\hline
\end{tabular}

Berdasarkan tabel 4.2 hasil dari pengelolaan data diperoleh nilai Variance Inflation Factor (VIF) tidak lebih dari 10 dan nilai Tolerance (TOL) tidak kurang dari 0,1 maka

dapat disimpulkan bahwa model regresi tidak memiliki masalah multikolinearitas.

\section{Uji Heteroskedastisitas}

Tabel 4.3 Nilai Uji Glesjer

\begin{tabular}{|l|l|l|}
\hline \multicolumn{1}{|c|}{ VARIABEL } & \multicolumn{1}{c|}{ Sig. } & \multicolumn{1}{c|}{ Kesimpulan } \\
\hline Kompensasi $\left(\mathrm{X}_{1}\right)$ & 0,721 & tidak terdapat gejala heteroskedastisitas \\
\hline Kedisiplinan $\left(\mathrm{X}_{2}\right)$ & 0,452 & tidak terdapat gejala heteroskedastisitas \\
\hline Pengalaman Kerja $\left(\mathrm{X}_{3}\right)$ & 0,73 & tidak terdapat gejala heteroskedastisitas \\
\hline
\end{tabular}

Sumber:Lampiran 5

Berdasarkan tabel 4.3 diatas menunjukkan bahwa Nilai Uji Glejser Kompensasi $\left(\mathrm{X}_{1}\right)$ 0,721, Kedisiplinan $\left(X_{2}\right)$ 0,452 dan Pengalaman kerja (X3) 0,73 hal tersebut menunjukan tidak

\section{Tabel 4.4}

One-Sample Kolmogorov-Smirnov Test

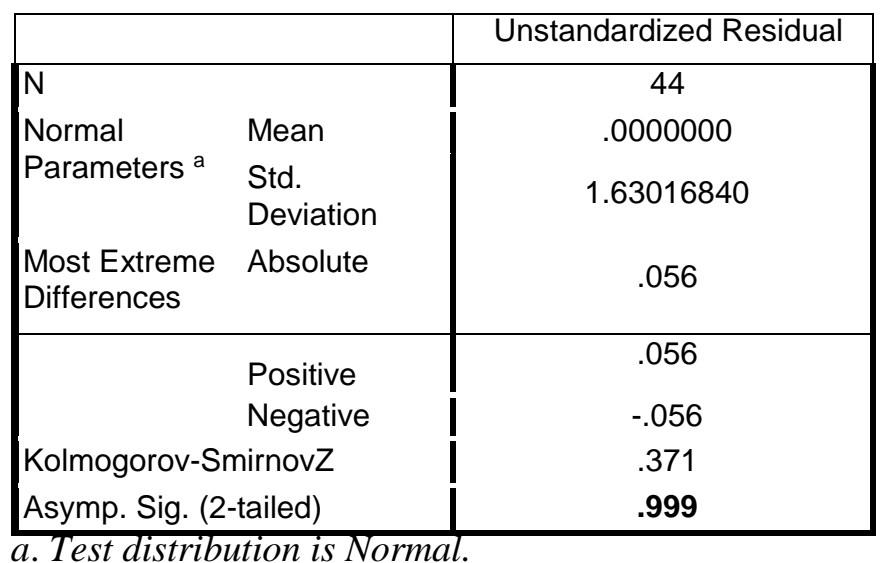

Berdasarkan output tabel 4.4 diketahui nilai signifikansi sebesar 0,999 lebih besar dari 0,05 dapat disimpulkan bahwa data yang di uji berdistribusi normal dan $\mathrm{H}_{\mathrm{O}}$ diterima. Maknanya semua variabel bebas bila ada ketidaksamaan dari residual untuk terdapat gejala heteroskedastisitas karena hasil sig. >0,05.

\section{Uji Normalitas}


Tabel 4.5

Uji Regresi Linier Berganda

Coefficients $^{\mathrm{a}}$

\begin{tabular}{|c|c|c|c|c|c|c|}
\hline \multirow{2}{*}{\multicolumn{2}{|c|}{ Model }} & \multicolumn{2}{|c|}{ Unstandardized Coefficients } & \multirow{2}{*}{$\begin{array}{l}\text { Standardi zed Coefficients } \\
\text { Beta }\end{array}$} & \multirow[b]{2}{*}{$\mathrm{T}$} & \multirow[b]{2}{*}{ Sig. } \\
\hline & & $B$ & Std. Error & & & \\
\hline \multirow[t]{4}{*}{1} & (Constant) & 3.335 & 2.117 & & 1.575 & 0,123 \\
\hline & $\left(\mathrm{X}_{1}\right)$ & 1.036 & 01464 & 0,585 & 7.075 & 0,000 \\
\hline & $\left(\mathrm{X}_{2}\right)$ & .450 & 0,163 & 0,236 & 2.761 & 0,009 \\
\hline & $\left(\mathrm{X}_{3}\right)$ & .656 & 0,126 & 0,364 & 4.490 & 0,000 \\
\hline
\end{tabular}

$\mathrm{Y}=3.335+1,036 \mathrm{X}_{1}+0,450 \mathrm{X}_{2}+0,656 \mathrm{X}_{3}$

1. Nilai konstanta 3.335 menunjukan apabila Kompensasi (X1), Kedisiplinan (X2) Dan Pengalaman Kerja (X3), bernilai 0, maka Kinerja Karyawan PT. Andre Teknik Mandiri Surabaya (Y) adalah sebesar 3.335. Hal ini berarti tanpa adanya atau sebelum variabel Kompensasi (X1), Kedisiplinan (X2) Dan Pengalaman Kerja (X3) dalam perusahaan maka besarnya Kinerja Karyawan di PT. Andre Teknik Mandiri Surabaya (Y) adalah sebesar 3.335.

2. Koefisien Regresi Kompensasi (X1) sebesar 1,036, artinya jika Kompensasi (X1) berubah maka Kinerja Karyawan (Y) meningkat sebesar 1,036. Dengan anggapan bahwa Kedisiplinan (X2) dan Pengalaman Kerja (X3) tetap atau konstan.
3. Koefisien Regresi Kedisiplinan (X2) sebesar 0,450, artinya jika Kedisiplinan (X2) berubah maka Kinerja Karyawan (Y) meningkat sebesar 0,450. Dengan anggapan bahwa Kompensasi (X1) dan Pengalaman Kerja (X3) tetap atau konstan.

4. Koefisien Regresi Pengalaman Kerja (X3) sebesar 0,656, artinya jika Pengalaman Kerja (X3) berubah maka Kinerja Karyawan (Y) meningkat sebesar 0,656. Dengan anggapan bahwa Kompensasi (X1) dan Kedisiplinan (X2) tetap atau konstan.

\section{Koefisien determinasi ( $\mathrm{R2}$ ) dan koefisien korelasi ganda}

Tabel 4.6

Hasil Analisis Koefisien determinasi (R2)

\begin{tabular}{|c|c|r|c|c|}
\hline Model & R & R Square & $\begin{array}{c}\text { Adjusted R } \\
\text { Square }\end{array}$ & $\begin{array}{c}\text { Std. Error of } \\
\text { the Estimate }\end{array}$ \\
\hline 1 & $0,874(\mathrm{a})$ & 0,764 & 0,746 & 1.6902 \\
\hline
\end{tabular}

Berdasarkan tabel 4.6 diperoleh nilai sebagai berikut:

1) Adjusted R Square $=0,746$ dapat dikatakan bahwa perubahan variabel terikat kinerja (Y) sebesar $74,6 \%$ disebabkan oleh variable Kompensasi (X1), Kedisiplinan
(X2) dan Pengalaman Kerja (X3) sedangkan sisanya sebesar $25,4 \%$ disebabkan oleh faktor- faktor lain diluar variable tersebut.

2) Nilai $R$ Square $=0,764$ artinya bahwa variable Kompensasi (X1), Kedisiplinan (X2), dan pengalaman 
Kerja (X3) mampu menjelaskan perubahan variabel terikat kinerja karyawan (Y) sebesar $76,4 \%$ sedangkan sisanya $23,6 \%$ disebabkan oleh faktor-faktor lain diluar variabel tersebut.

3) $\mathrm{R}=0,874$ artinya kuatnya hubungan antar variabel Kompensasi (X1),
Kedisiplinan (X2), dan Pengalaman Kerja (X3) bersama-sama terhadap variable (Y) yaitu $87,4 \%$.

Uji Hipotesis

1. Uji t (Parsial)

Tabel 4.7

Hasil Analisis Uji Koefisien Parsial (Uji t)

\begin{tabular}{|c|c|c|c|c|c|c|}
\hline \multirow{2}{*}{\multicolumn{2}{|c|}{ Model }} & \multicolumn{2}{|c|}{$\begin{array}{l}\text { Unstandardized } \\
\text { Coefficients }\end{array}$} & \multirow{2}{*}{$\begin{array}{l}\text { Standardized } \\
\text { Coefficients } \\
\text { Beta }\end{array}$} & \multirow[b]{2}{*}{$\mathrm{T}$} & \multirow[b]{2}{*}{ Sig. } \\
\hline & & B & Std. Error & & & \\
\hline \multirow[t]{4}{*}{1} & (Constant) & 3.335 & 2.117 & & 1.575 & 0,123 \\
\hline & $\left(X_{1}\right)$ & 1.036 & 01464 & 0,585 & 7.075 & 0,000 \\
\hline & $\left(X_{2}\right)$ & .450 & 0,163 & 0,236 & 2.761 & 0,009 \\
\hline & $\left(X_{3}\right)$ & .656 & 0,126 & 0,364 & 4.490 & 0,000 \\
\hline
\end{tabular}

1. Berdasarkan tabel 4.7, menunjukkan hasil terhadap variabel Kompensasi (X1) diperoleh t hitung sebesar 7,075 $>\mathrm{t}$ tabel sebesar 2,018. Dengan signifikan sebesar 5\% maka Ho ditolak dan $\mathrm{Ha}$ diterima. Hal ini berarti variabel Kompensasi (X1) berpengaruh signifikan terhadap Kinerja Karyawan PT. Andre Teknik Mandiri Surabaya.

2. Berdasarkan tabel 4.7, menunjukkan hasil terhadap variabel Kedisiplinan (X2) diperoleh t hitung sebesar 2,761 $>\mathrm{t}$ tabel sebesar 2,018. Dengan signifikan sebesar 5\% maka Ho ditolak dan $\mathrm{Ha}$ diterima. Hal ini berarti variabel Kedisiplinan (X2) berpengaruh signifikan terhadap Kinerja Karyawan PT. Andre Teknik Mandiri Surabaya.

3. Berdasarkan tabel 4.7, menunjukkan hasil terhadap variabel Pengalaman Kerja (X3) diperoleh t hitung sebesar $4,490>\mathrm{t}$ tabel sebesar 2,018. Dengan signifikan sebesar 5\% maka Ho ditolak dan $\mathrm{Ha}$ diterima. Hal ini berarti variabel Pengalaman Kerja (X3) berpengaruh signifikan terhadap Kinerja Karyawan PT. Andre Teknik Mandiri Surabaya

\section{KESIMPULAN DAN REKOMENDASI Kesimpulan}

Berdasarkan hasil penelitian dapat ditarik kesimpulan sebagai berikut:

1. Kompensasi $\left(\mathrm{X}_{1}\right)$ secara parsial berpengaruh signifikan terhadap Kinerja pegawai tetap di PT. Andre Teknik Mandiri Surabaya.

2. Kedisiplinan $\left(\mathrm{X}_{2}\right)$ secara parsial berpengaruh signifikan terhadap Kinerja pegawai tetap di PT. Andre Teknik Mandiri Surabaya.

3. Pengalaman Kerja ( $\left.\mathrm{X}_{3}\right)$ secara parsial berpengaruh signifikan terhadap Kinerja pegawai tetap di PT. Andre Teknik Mandiri Surabaya.

\section{Rekomendasi}

Berdasarkan hasil analisis, pembahasan, dan kesimpulan penelitian, maka rekomendasi dari peneliti dapat diberikan sebagai 
berikut:

1 Bagi Perusahaan PT. Andre Teknik Mandiri Surabaya :

Berdasarkan hasil uji t perhitungan variabel Kompensasi (X1) memiliki nilai paling tinggi sebesar 7,075 jika dibandingkan dengan nilai variabel Kedisiplinan (X1) sebesar 2,761 dan Pengalaman kerja (X3) sebesar 4,490, maka pihak PT. Andre Teknik Mandiri Surabaya harus tetap mempertahankan pemberian Kompensasi meliputi gaji,tunjangan kesahatan, dan THR yang diterima sesuai tanggungjawab yang diberikan dan terus meningkatkan kinerja karyawannya agar tercapai secara maksimal.

2 Bagi Peneliti Selanjutnya :

Hasil penelitian ini dapat digunakan sebagai referensi bagi peneliti selanjutnya dengan memperbanyak jumlah variabel dan menggunakan teknik analisis yang berbeda.

\section{DAFTAR PUSTAKA}

Bejo Siswanto Sastrohadiwiryo. 2010.

Manajemen Tenaga Kerja Indonesia Pendekatan Administrative dan Operasional. Jakarta: Bumi Aksara.
Hasibuan, Malayu S.P. 2013. Manajemen Sumber Daya Manusia. Edisi Revisi. Jakarta: Bumi Aksara.

HRD PT. Andre Teknik Mandiri Surabaya, 2017, Data Kepegawaian PT. Andre Teknik Mandiri , Surabaya.

Poltak Sinambela, Lijan. 2016. Manajemen Sumber Daya Manusia. Jakarta: PT Bumi Aksara.

Rivai, Veithzal dan Sagala, Ella Jauvani. 2011. Manajemen Sumber Daya Manusia untuk Perusahaan dari Teori ke Praktik. Jakarta: PT Raja Grafindo.

Sugiyono. 2015. Metode Penelitian Pendidikan. Bandung: CV. Alpabeta.

Sutrisno, Edi. 2013. Manajemen Sumber daya manusia. Edisi Pertama. Jakarta: Kencana Prenada Media Group. 